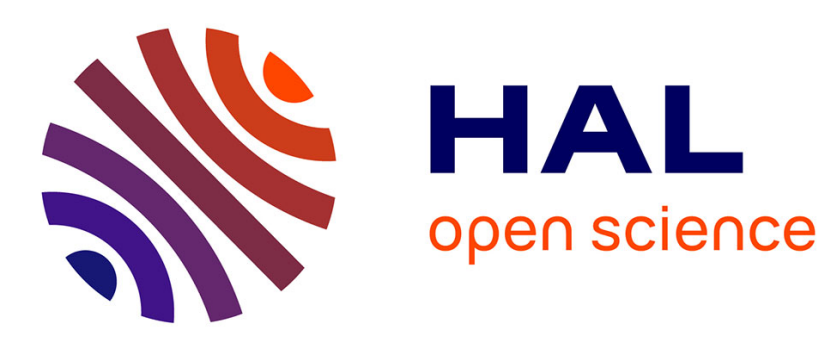

\title{
Isolation of plant cell wall proteins
}

Elisabeth Jamet, Georges Boudart, Gisèle Borderies, Stéphane Charmont, Claude Lafitte, Michel Rossignol, Hervé Canut, Rafael F. Pont-Lezica

\section{To cite this version:}

Elisabeth Jamet, Georges Boudart, Gisèle Borderies, Stéphane Charmont, Claude Lafitte, et al.. Isolation of plant cell wall proteins. Posch, A. Applications and Protocols in Expression Proteomics, vol 2, Humana Press Inc., pp.187-201, 2007, Methods in Molecular Biology, vol 425. hal-00169382

\section{HAL Id: hal-00169382 \\ https://hal.science/hal-00169382}

Submitted on 3 Sep 2007

HAL is a multi-disciplinary open access archive for the deposit and dissemination of scientific research documents, whether they are published or not. The documents may come from teaching and research institutions in France or abroad, or from public or private research centers.
L'archive ouverte pluridisciplinaire HAL, est destinée au dépôt et à la diffusion de documents scientifiques de niveau recherche, publiés ou non, émanant des établissements d'enseignement et de recherche français ou étrangers, des laboratoires publics ou privés. 


\title{
Published In: Methods in Molecular Biology, vol. 425: Applications and Protocols in Expression Proteomics, vol. 2, Anton Posch Ed., Humana Press Inc., Totowa, NJ, USA, pp 187-201.
}

\section{Chapter 17}

\section{Isolation of plant cell wall proteins}

Running head: Plant cell wall proteins

\author{
Elisabeth JAMET, Georges BOUDART, Gisèle BORDERIES, \\ Stéphane CHARMONT ${ }^{1}$, Claude LAFITTE, Michel ROSSIGNOL, Hervé CANUT, \\ Rafael PONT-LEZICA ${ }^{2}$
}

Surfaces Cellulaires et Signalisation chez les Végétaux, UMR 5546 CNRS-Université Paul Sabatier-Toulouse III, Pôle de Biotechnologie végétale, 24 Chemin de Borde Rouge, BP 42617 Auzeville, 31326 Castanet-Tolosan, France

\footnotetext{
${ }^{1}$ Present address: Novartis Pharma AG, BioMarker Development/IEP PROTEOMICS, WKL136.1.12, CH-4002 Basel, Switzerland
}

${ }^{2}$ Corresponding author: Pr Rafael PONT-LEZICA, Surfaces Cellulaires et Signalisation chez les Végétaux, UMR 5546 CNRS-Université Paul Sabatier-Toulouse III, Pôle de Biotechnologie végétale, 24 Chemin de Borde Rouge, BP 42617 Auzeville, 31326 CastanetTolosan, France. Phone number: + 33 (0)562 1935 16, fax: + 33 (0)562 1935 02, e-mail: lezica@scsv.ups-tlse.fr

\begin{abstract}
The quality of a proteomic analysis of a cell compartment strongly depends on the reliability of the isolation procedure for the cell compartment of interest. Plant cell walls possess specific drawbacks: (i) the lack of a surrounding membrane may result in the loss of cell wall proteins (CWP) during the isolation procedure; (ii) polysaccharide networks of cellulose, hemicelluloses and pectins form potential traps for contaminants such as intracellular proteins; (iii) the presence of proteins interacting in many different ways with the polysaccharide matrix require different procedures to elute them from the cell wall. Three categories of CWP are distinguished: labile proteins that have little or no interactions with cell wall components, weakly bound proteins extractable with salts, and strongly bound proteins. Two alternative protocols are decribed for cell wall proteomics: (i) non-destructive techniques allowing the extraction of labile or weakly bound CWP without damaging the plasma membrane; (ii) destructive techniques to isolate cell walls from which weakly or strongly bound CWP can be extracted. These protocols give very low levels of contamination by
\end{abstract}


intracellular proteins. Their application should lead to a realistic view of the cell wall proteome at least for labile and weakly bound CWP extractable by salts.

Key Words: Arabidopsis thaliana, cell wall, proteomics, plant, bioinformatics, cell wall protein, cell fractionation

\section{Introduction}

Plant cell wall proteins (CWP) present specific complexities in addition to the difficulties usually encountered in proteome analysis, such as protein separation and detection of scarce proteins (1). They are embedded in an insoluble polysaccharide matrix and interact with other cell wall components, making their extraction challenging. Current models of cell wall structure describe the arrangement of their components into two structurally independent and interacting networks, embedded in a pectin matrix $(2,3)$. Cellulose microfibrils and hemicelluloses constitute the first network; the second one is formed by structural proteins. Three types of CWP can be distinguished, according to their interactions with cell wall components (4). CWP can have little or no interactions with cell wall components and thus move freely in the extracellular space. Such proteins can be found in liquid culture media of cell suspensions and seedlings or can be extracted with low ionic strength buffers. We call this fraction "labile proteins", most of them have acidic pI ranging from 2 to 6 (Fig. 1A). Alternatively, CWP might be weakly bound to the matrix by Van der Waals interactions, hydrogen bonds, hydrophobic or ionic interactions. Such proteins may be extracted by salts and most of them have basic pI ranging from 8 to 11 (Fig. 1B) so that they are positively charged at the acidic $\mathrm{pH}$ of cell walls. Even though most of the cell wall polysaccharides are neutral, negatively charged pectins contain polygalacturonic acid that provides negative charges for interactions with basic proteins.

A. labile proteins

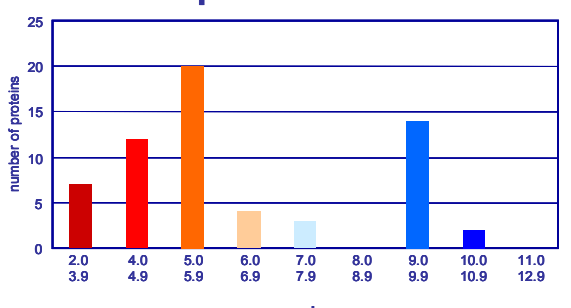

\section{B. salt extracted proteins}

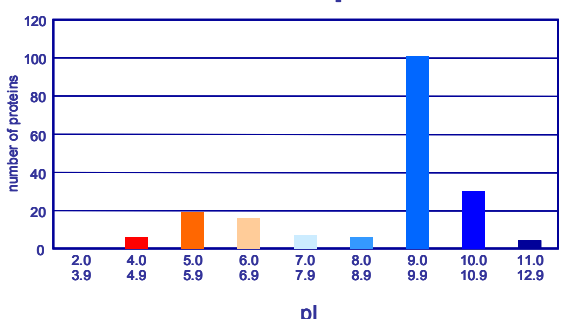

C. all proteins

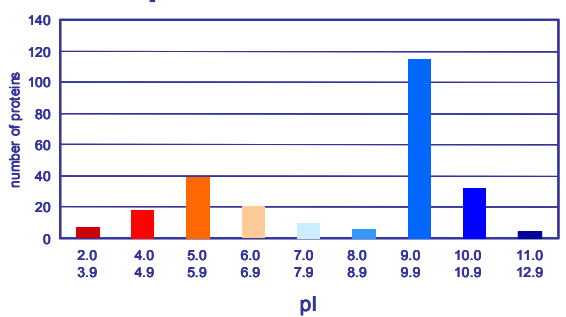

Fig. 1. pIs of labile and weakly-bound CWP. pIs of CWP identified in several proteomic studies (4) were calculated (www.iut-arles.up.univ-mrs.fr/w3bb/d_abim/compo-p.html) after removal of their predicted signal peptides (http://psort.nibb.ac.jp/form.html). Three groups of proteins were considered: (A) labile proteins; (B) salt-extracted proteins, i.e. proteins extracted with salt solutions or chelating agent; (C) all proteins. Reprinted from (4), Copyright (2005), with permission from Elsevier. 
Such interactions would be modulated by $\mathrm{pH}$, degree of pectin esterification, $\mathrm{Ca}^{2+}$ concentration, and by the mobility and diffusion coefficients of these macromolecules $(3,5)$. Finally, CWP can be strongly bound to cell wall components so that they are still resistant to salt-extraction. As examples, extensins are cross-linked by covalent links $(6,7)$ and peroxidases can have a high affinity for $\mathrm{Ca}^{2+}$-pectate $(\boldsymbol{8})$.

The available techniques described in this chapter allow the extraction of labile and weakly bound CWP. Since labile proteins can be lost during the preparation of cell walls, they must be extracted from tissues by non-destructive techniques such as vacuum infiltration (9), or recovered from liquid culture media from cell suspension cultures or seedlings $(10,11)$. Weakly bound CWP can be extracted with salts or chelating agents from living cells with non-destructive techniques $(\mathbf{9}, \mathbf{1 0})$ or from purified cell walls with destructive techniques. At present, there is no efficient procedure to release CWP strongly bound to the extracellular matrix. Structural proteins, for instance extensins or PRP, can be cross-linked via diisodityrosine bonds $(\mathbf{6 , 1 2})$. Purified cell walls appear as the most suitable material to isolate such proteins. However, until now, extensins have only been eluted with salts prior to their insolubilization from cell suspension cultures (13).

\section{Materials}

A major problem in proteomics is the occurrence of keratins that can contaminate materials and working solutions. The presence of keratins can prevent the identification of proteins of interest by mass spectrometry. It is necessary to pay attention to all possible sources of contamination at all steps of the following protocols. Powder-free gloves should be permanently worn and washed with soap before their first use. Chemicals should be reserved for proteomic studies and should not be manipulated with spatula. Buffers should be filtered on $0.22 \mu \mathrm{m}$ pore size filters. Glass plates for electrophoresis should be cleaned with alcohol before use.

\subsection{Extraction of labile or weakly bound CWP by non-destructive techniques}

2.1.1. CWP extraction and analysis from liquid culture medium of seedlings

1. Murashige and Skoog (MS) culture medium: Murashige and Skoog (14) liquid medium (Sigma Chemical, St Louis, MO, USA) is supplemented with $10 \mathrm{~g} / \mathrm{L}$ sucrose and adjusted to $\mathrm{pH} 5.8$ with $\mathrm{KOH}$.

2. PVPP (Sigma, St. Louis, MO, USA) is treated with acid to increase polymerization and to remove metal ions and contaminants. One g PVPP in $10 \mathrm{~mL} 10 \% \mathrm{HCl}$ is boiled for $10 \mathrm{~min}$, filtered through a G4 filter, and rinsed until neutral $\mathrm{pH}$ is reached. The residue is dehydrated with acetone and grinded in a mortar to obtain a fine powder (15).

3. Low binding $12 \mathrm{kDa}$ cutoff Spectra/Por ${ }^{\circledR}$ cellulose ester $(\mathrm{CE})$ dialysis bags (Merck Eurolab Poly Labo, Strasbourg, France).

4. Centriprep ${ }^{\circledR}$ device (MWCO: $10 \mathrm{kDa}$ ) (Millipore Corporation, Bedford, MA, USA).

5. Bradford protein assay (Coomassie ${ }^{\circledR}$ Protein assay Reagent Kit, Pierce, Rockford, IL, USA) (16).

6. Immobilized $\mathrm{pH}$ gradient (IPG) buffers and $13 \mathrm{~cm}$-strips $\mathrm{pH}$ 4-7 or 6-11 (GE Healthcare Europe GmbH, Orsay, France).

7. 2-DE (2-dimensional electrophoresis) sample buffer: $7 \mathrm{M}$ urea, $2 \mathrm{M}$ thiourea, 4\% (w/v) CHAPS, $65 \mathrm{mM}$ DTE, 0.5\% (v/v) IPG buffer ( $\mathrm{pH} 4-7$ or 6-11), bromophenol blue trace. 
2.1.2. CWP extraction and analysis from cell suspension cultures

1. Gamborg liquid medium: Gamborg B5 medium supplemented with $20 \mathrm{~g} / \mathrm{L}$ sucrose, $2.5 \mu \mathrm{M}$ naphthalene acetic acid (Sigma Chemical, St Louis, MO, USA) and adjusted to $\mathrm{pH} 5.7$ with $\mathrm{KOH}(17)$.

2. Cell washing buffer: $50 \mathrm{mM}$ sodium acetate buffer $\mathrm{pH} 6.5,10 \mathrm{mM}$ DTT, $1 \mathrm{mM}$ PMSF, $1 \%$ ethanol, $50 \%$ glycerol.

3. $\mathrm{C} 1$ protein extraction buffers: $0.15 \mathrm{M} \mathrm{NaCl}$ in cell washing buffer.

4. $\mathrm{C} 2$ protein extraction buffer: $1 \mathrm{M} \mathrm{NaCl}$ in cell washing buffer.

5. $\mathrm{C} 3$ protein extraction buffer: $0.2 \mathrm{M} \mathrm{CaCl}_{2}$ dihydrate in cell washing buffer.

6. $\mathrm{C} 4$ protein extraction buffer: $2 \mathrm{M} \mathrm{LiCl}$ in cell washing buffer.

7. C5 protein extraction buffer: $50 \mathrm{mM}$ 1,2-cyclohexanediamine tetracetic acid (CDTA) in cell washing buffer.

8. Low binding $2 \mathrm{kDa}$ cutoff Spectra/Por ${ }^{\circledR} \mathrm{CE}$ dialysis bags (Merck Eurolab Poly Labo, Strasbourg, France).

9. One mL Hi-Trap SP Sepharose cation exchanger (GE Healthcare Europe GmbH, Orsay, France).

10. Hi-Trap SP equilibration buffer: $10 \mathrm{mM}$ MES-KOH, $\mathrm{pH}$ 5.2.

11. Hi-Trap SP elution buffer: $10 \mathrm{mM}$ MES-KOH, $\mathrm{pH}$ 5.2, $2 \mathrm{M} \mathrm{NaCl}$.

12. Econo-Pac ${ }^{\circledR} 10 \mathrm{DG}$ desalting column (Bio-Rad, Hercules, CA,USA).

13. Desalting column equilibration buffer: $50 \mathrm{mM}$ ammonium formate.

14. Bradford protein assay (Coomassie ${ }^{\circledR}$ Protein assay Reagent Kit, Pierce, Rockford, IL, USA) (16).

15. 1-DE (1-dimensional electrophoresis) sample buffer: $62 \mathrm{mM}$ Tris- $\mathrm{HCl}, \mathrm{pH} 6.8,2 \%$ SDS, $10 \%$ glycerol, $5 \%$ mercapto-ethanol.

16. Resuspending solution: $1 \mathrm{M}$ thiourea, $10 \mathrm{mM}$ DTT, $1 \%(\mathrm{v} / \mathrm{v})$ protease inhibitor cocktail for plant (Sigma, St. Louis, MO, USA) in UHQ water (see Note 1). Prepare as required.

17. Immobilized $\mathrm{pH}$ gradient (IPG) buffers and 13 cm-strips $\mathrm{pH}$ 4-7 or 6-11 (GE Healthcare Europe GmbH, Orsay, France).

18. 2-DE sample buffer: $7 \mathrm{M}$ urea, $2 \mathrm{M}$ thiourea, 4\% (w/v) CHAPS, $65 \mathrm{mM}$ DTE, $0.5 \%$ (v/v) IPG buffer ( $\mathrm{pH}$ 4-7 or 6-11), bromophenol blue trace.

2.1.3. Extraction and analysis of CWP from rosette leaves

2.1.3.1. Extraction of proteins

1. Recovering solution: $0.3 \mathrm{M}$ mannitol, $66 \mathrm{mM}$ DTT, $330 \mathrm{mM}$ thiourea, $3.3 \%$ (v/v) protease inhibitor cocktail for plant (Sigma, St. Louis, MO, USA) (see Note 1). Prepare as required.

2. $\mathrm{R} 1$ protein extraction buffer: $1 \mathrm{M} \mathrm{NaCl}$, in recovering solution. Adjust $\mathrm{pH}$ to 6.9 with 0.5 $\mathrm{N} \mathrm{NaOH}$. Prepare as required

3. $\mathrm{R} 2$ protein extraction buffer: $0.2 \mathrm{M} \mathrm{CaCl}_{2}$ dihydrate, in recovering solution. Adjust $\mathrm{pH}$ to 6.9 with $0.5 \mathrm{~N} \mathrm{NaOH}$. Prepare as required.

4. $\mathrm{R} 3$ protein extraction buffer: $2 \mathrm{M} \mathrm{LiCl}, 0.3$ in recovering solution. Adjust $\mathrm{pH}$ to 6.9 with 1 $\mathrm{N} \mathrm{NaOH}$. Prepare as required.

5. R4 protein extraction buffer: $50 \mathrm{mM} \mathrm{CDTA}$, in recovering solution. Adjust $\mathrm{pH}$ to 6.9 with $5 \mathrm{~N} \mathrm{NaOH}$. Prepare as required.

6. Malate dehydrogenase $(\mathrm{MDH})$ assay mixture: $50 \mathrm{mM}$ Tris-HCl, $\mathrm{pH} 7.8(2.15 \mathrm{~mL}), 50$ $\mathrm{mM} \mathrm{MgCl} 2$ hexa-hydrate $(300 \mu \mathrm{L}), 150 \mathrm{mM}$ DTT $(100 \mu \mathrm{L}), 10 \mathrm{mM}$ NADP $(150 \mu \mathrm{L}), 30$ $\mathrm{mM}$ malic acid $(300 \mu \mathrm{L})$. Store DTT and NADP solutions in single use aliquots at $-20^{\circ} \mathrm{C}$. 
Store malic acid solution at $-20^{\circ} \mathrm{C}$ no longer than one month. Prepare the $\mathrm{MDH}$ assay mixture as required

\subsubsection{Analysis of labile CWP}

1. Low binding $2 \mathrm{kDa}$ cutoff Spectra/Por ${ }^{\circledR} \mathrm{CE}$ dialysis bags (Merck Eurolab Poly Labo, Strasbourg, France). Store at $-20^{\circ} \mathrm{C}$.

2. Resuspending solution: $1 \mathrm{M}$ thiourea, $10 \mathrm{mM}$ DTT, protease inhibitor cocktail (1\% $\mathrm{v} / \mathrm{v}$ ) in UHQ water. Prepare as required.

3. Immobilized $\mathrm{pH}$ gradient (IPG) buffers and $7 \mathrm{~cm}$-strips $\mathrm{pH}$ 4-7 (GE Healthcare Europe GmbH, Orsay, France).

4. 2 DE-sample buffer: $7 \mathrm{M}$ urea, $2 \mathrm{M}$ thiourea, $4 \%$ (w/v) CHAPS, $65 \mathrm{mM} \mathrm{DTE}, 0.5 \%$ (v/v) IPG buffer ( $\mathrm{pH}$ 4-7 or 6-11), bromophenol blue trace.

\subsubsection{Analysis of weakly-bound CWP}

1. Low binding $2 \mathrm{kDa}$ cutoff Spectra/Por ${ }^{\circledR} \mathrm{CE}$ dialysis bags (Merck Eurolab Poly Labo, Strasbourg, France). Store at $-20^{\circ} \mathrm{C}$.

2. One mL Hi-Trap SP Sepharose cation exchanger (GE Healthcare Europe GmbH, Orsay, France).

3. Hi-Trap SP equilibration buffer: $10 \mathrm{mM}$ MES-KOH, $\mathrm{pH} 5.2$.

4. Hi-trap SP elution buffer: $10 \mathrm{mM}$ MES-KOH, $\mathrm{pH} 5.2, \mathrm{NaCl} 2 \mathrm{M}$.

5. Econo-Pac ${ }^{\circledR} 10 \mathrm{DG}$ desalting column (Bio-Rad, Hercules, CA, USA).

6. Desalting column equilibration buffer: $50 \mathrm{mM}$ ammonium formate.

7. 1-DE sample buffer: $62 \mathrm{mM}$ Tris- $\mathrm{HCl}, \mathrm{pH} 6.8,2 \% \mathrm{SDS}, 10 \%$ glycerol, 5\% mercaptoethanol.

8. Resuspending solution: $1 \mathrm{M}$ thiourea, $10 \mathrm{mM}$ DTT, $1 \%(\mathrm{v} / \mathrm{v})$ protease inhibitor cocktail in UHQ water. Prepare as required.

9. Immobilized $\mathrm{pH}$ gradient (IPG) buffers and $7 \mathrm{~cm}$-strips $\mathrm{pH}$ 4-7 (GE Healthcare Europe GmbH, Orsay, France).

10. 2 DE-sample buffer: $7 \mathrm{M}$ urea, $2 \mathrm{M}$ thiourea, $4 \%$ (w/v) CHAPS, $65 \mathrm{mM} \mathrm{DTE,} 0.5 \%$ (v/v) IPG buffer ( $\mathrm{pH}$ 4-7 or 6-11), bromophenol blue trace.

\subsection{Extraction of weakly bound CWP by destructive techniques}

\subsubsection{Cell wall preparation}

1. MS solid medium: Murashige and Skoog (14) liquid medium (Sigma Chemical, St Louis, MO, USA) is supplemented with $20 \mathrm{~g} / \mathrm{L}$ sucrose and $12 \mathrm{~g} / \mathrm{L}$ agar, and adjusted to $\mathrm{pH} 5.8$ with $\mathrm{KOH}$.

2. PVPP (Sigma, St. Louis, MO, USA) is treated with acid to increase polymerization and to remove metal ions and contaminants. One g PVPP in $10 \mathrm{~mL} 10 \% \mathrm{HCl}$ is boiled for $10 \mathrm{~min}$, filtered through a G4 filter, and rinsed until neutral $\mathrm{pH}$ is reached. The residue is dehydrated with acetone and grinded in a mortar to obtain a fine powder (15).

3. Nylon nets ( $1.5 \mathrm{~mm}$ pore size and $25 \mu \mathrm{m}$ pore size).

4. Waring blender with a 2 L flask (SEB Moulinex, Ecully, France).

5. Grinding buffer: $10 \mathrm{mM}$ acetate buffer, $\mathrm{pH} 4.6,0.4 \mathrm{M}$ sucrose, $0.2 \%(\mathrm{v} / \mathrm{v})$ protease inhibitor cocktail for plant (Sigma, St. Louis, MO, USA) (see Note 1).

6. Cell wall purification buffers: $5 \mathrm{mM}$ acetate buffer, $\mathrm{pH} 4.6,0.6 \mathrm{M}$ or $1 \mathrm{M}$ sucrose, 0.2 $\%(\mathrm{v} / \mathrm{v})$ protease inhibitor cocktail.

7. Cell wall washing buffer: $5 \mathrm{mM}$ acetate buffer, $\mathrm{pH} 4.6$. 
2.2.2 Extraction and separation of proteins

1. H1 protein extraction buffer: $5 \mathrm{mM}$ acetate buffer, $\mathrm{pH} 4.6,0.2 \mathrm{M} \mathrm{CaCl}_{2}, 0.1 \%$ protease inhibitor cocktail for plant (Sigma, St. Louis, MO, USA).

2. $\mathrm{H} 2$ protein extraction buffer: $5 \mathrm{mM}$ acetate buffer, $\mathrm{pH} 4.6,2 \mathrm{M} \mathrm{LiCl}, 0.1 \%$ protease inhibitor cocktail.

3. Econo-Pac ${ }^{\circledR} 10 \mathrm{DG}$ desalting column (Bio-Rad, Hercules, CA,USA).

4. Desalting column equilibration buffer: $50 \mathrm{mM}$ ammonium formate.

5. Bradford protein assay (Coomassie ${ }^{\circledR}$ Protein assay Reagent Kit, Pierce, Rockford, IL, USA) (16).

6. 1-DE sample buffer: $62 \mathrm{mM}$ Tris $\mathrm{pH} 6.8(\mathrm{HCl}), 2 \% \mathrm{SDS}, 10 \%$ glycerol, $5 \%$ mercaptoethanol.

\section{Methods}

The choice of a protocol to extract CWP for proteomic analysis is dependent on the plant material and of the type of proteins to be released from cell walls. Working on living cells is probably the best solution to avoid intracellular contamination. This is possible for cell suspension cultures or seedlings grown in liquid medium as well as for any plant organ that can be infiltrated under vacuum with extraction buffers. Both labile and weakly-bound CWP can be released. When this is not possible, it is necessary to purify cell walls. The main problem is to avoid intracellular contaminants that will stick non-specifically to cell walls. Only weakly-bound CWP can be extracted from purified cell walls since labile CWP are lost during cell wall preparation.

Another important point is the choice of the extraction solution. For example, a solution of $0.3 \mathrm{M}$ mannitol infiltrated in living tissues such as leaves can solubilize a few CWP expected to be located only in intercellular spaces. Indeed, identified proteins are acidic, suggesting no ionic interactions with negatively charged cell wall components (9). $\mathrm{NaCl}$ is usually used for extraction of proteins retained by ionic interactions in the cell wall. $\mathrm{LiCl}$ can extract hydroxyproline-rich glycoproteins from intact cells in Chlamydomonas reinhardii (18). Calcium chloride is probably the most efficient salt to extract CWP $(\mathbf{9}, 19)$. The ability of acidic and neutral carbohydrates to strongly chelate calcium $(20,21)$ might explain, through a competition mechanism, that proteins or glycoproteins weakly bound to cell wall polysaccharides can be selectively solubilized by $\mathrm{CaCl}_{2}$. CDTA, a chelating agent, solubilizes $\mathrm{Ca}^{2+}$-pectate. It releases a small number of proteins having domains of interaction with polysaccharides, notably proteins showing homology to lectins. This suggests an interaction of these proteins with polysaccharides associated to pectins (9).

\subsection{Extraction of labile or weakly bound CWP by non-destructive techniques}

3.1.1. Liquid culture medium of seedlings

1. Soak $A$. thaliana ecotype Columbia seeds (see Note 2) in tap water for $2 \mathrm{~h}$, then sterilize in diluted bleach $(2.4 \% \mathrm{w} / \mathrm{v})$ for $45 \mathrm{~min}$, and rinse several times with deionized water.

2. Sterilized seeds $(100 \mathrm{mg})$ are germinated and grown in MS liquid culture medium in ten 1 L-flasks on a rotary shaker $(90 \mathrm{rpm})$ at $26{ }^{\circ} \mathrm{C}$ in the dark (22). Each flask contains $130 \mathrm{~mL}$ of culture medium. After 14 days, etiolated seedlings are harvested and the culture medium is filtered through nylon net $(60 \mu \mathrm{m})$ to remove cell debris. 
3. Collect $900 \mathrm{~mL}$ of culture medium (see Note 3). Mix with $9 \mathrm{~g}$ PVPP. Shake the mixture at $4{ }^{\circ} \mathrm{C}$ for at least $30 \mathrm{~min}$, filter and centrifuge to pellet the insoluble residue. Dialyze against $10 \mathrm{~L}$ distilled water during $10-12 \mathrm{~h}$ at $4{ }^{\circ} \mathrm{C}$ using a dialysis bag (MWCO: $12 \mathrm{kDa}$ ) with 3 changes. Reduce the volume of the sample by repeated centrifugations $\left(3500 \times g\right.$ for $15 \mathrm{~min}$ at $\left.4{ }^{\circ} \mathrm{C}\right)$ through a Centriprep ${ }^{\circledR}$ device (MWCO: $10 \mathrm{kDa}$ ) to about $1 \mathrm{~mL}$.

4. Quantify proteins using the Bradford protein assay.

5. Dilute $250 \mu \mathrm{g}$ proteins extracted from culture medium with $250 \mu \mathrm{L}$ 2-DE sample buffer. Proteins are separated by 2-DE using $13 \mathrm{~cm}$ - IPG gel strips $\mathrm{pH} 4-7$ or 6-11 for the first dimension.

\subsubsection{Cell suspension cultures}

1. A cell suspension culture of $A$. thaliana ecotype Columbia is grown on Gamborg liquid medium. From this culture, $50 \mathrm{~mL}(25 \mathrm{~g})$ is transferred every 2 weeks to $250 \mathrm{~mL}$ fresh medium in $1 \mathrm{~L}$ Erlenmeyer flask and shaken at $70 \mathrm{rpm}$ in an orbital shaker, under continuous light $\left(30 \mu \mathrm{E} \cdot \mathrm{m}^{-2} \cdot \mathrm{s}^{-1}\right)$ at $22^{\circ} \mathrm{C}$.

2. Wash cells of 7-day old $A$. thaliana suspension culture with water and pellet them by centrifugation at $200 \times g$. Plasmolyze by successive immersion in $25 \%$ glycerol, $50 \%$ glycerol for $10 \mathrm{~min}$ each, and finally wash in $50 \%$ cold glycerol. All subsequent extractions are performed at $0^{\circ} \mathrm{C}$ except otherwise stated.

3. Prior to protein extraction, wash cells with cell washing buffer in order to remove contaminant proteins coming from broken cells that non-specifically stick to cell walls.

4. Extract proteins by washings of the plasmolyzed cells under gentle stirring ( $30 \mathrm{~min})$ in the proportion of $25 \mathrm{~mL}$ of pelleted cells per $50 \mathrm{~mL}$ of solution. First extraction is performed with $\mathrm{C} 1$ buffer.

5. Wash cells with the same extraction buffer, then with $50 \%$ glycerol before centrifugation at $200 \times g$ for 5 min.

6. Extract weakly-bound CWP with $\mathrm{C} 2, \mathrm{C} 3, \mathrm{C} 4$ or $\mathrm{C} 5$ buffer in the same way (see Note 4).

7. Exhaustively dialyze protein extracts at $4{ }^{\circ} \mathrm{C}$ against $20 \mathrm{~L} \mathrm{H}_{2} \mathrm{O}$ using a dialysis bag (MWCO: $2 \mathrm{kDa}$ ). Measure the protein content of each extract using the Bradford protein assay.

8. Dialyze against Hi-Trap SP equilibration buffer and apply to a Hi-Trap SP Sepharose column equilibrated with Hi-Trap SP equilibration buffer at $1 \mathrm{~mL} \cdot \mathrm{min}^{-1}$. Elute the retained basic proteins with Hi-Trap SP elution buffer at $1 \mathrm{~mL} \cdot \mathrm{min}^{-1}$. Desalt the basic proteins on an Econo-Pac ${ }^{\circledR}$ 10DG desalting column equilibrated with desalting column equilibration buffer. Freeze-dry the eluate. Resuspend the dry residue in $40 \mu \mathrm{L}$ 1-DE sample buffer and separate proteins by 1-DE on a $10 \%-17 \%$ gradient polyacrylamide gel $(16.5 \times 13.5 \times 0.15 \mathrm{~cm})$.

9. Freeze-dry the acidic and neutral proteins from the Hi-Trap SP Sepharose column effluent. Solubilize the dry residue with a minimal volume of resuspending solution and desalt on an Econo-Pac ${ }^{\circledR} 10 \mathrm{DG}$ desalting column. Freeze-dry the proteins, dissolve in 2-DE sample buffer and perform a 2-DE using a 7 cm-IPG gel strip pH 4-7 for the first dimension.

\subsubsection{Rosette leaves}

\subsubsection{Extraction of proteins}

1. Sterilize $A$. thaliana ecotype Columbia seeds by soaking in diluted bleach $(2.6 \% \mathrm{w} / \mathrm{v})$ for $5 \mathrm{~min}$ and rinse several times with deionized water. Sow the seeds on humid compost in $10 \times 10 \mathrm{~cm}$ pots and cover the pots with a plastic film. Remove the plastic 
film after $48 \mathrm{~h}$ and transfer the cultures in a growth chamber at $70 \%$ humidity, with a photoperiod of $9 \mathrm{~h}$ light at $110 \mu \mathrm{E} \cdot \mathrm{m}^{-2} \mathrm{~s}^{-1}$ at $22^{\circ} \mathrm{C}$, and $15 \mathrm{~h}$ dark at $20^{\circ} \mathrm{C}$. Plants should be moderately watered with a nutrient solution once a week.

2. Remove carefully 4- to 5-week-old plants (Fig. 2A) from the pots and wash compost off with deionized water. Cotyledons and yellowish leaves should be systematically removed from plants. Process whole plants for vacuum-infiltration as follows. Make a small noose with a piece of string and pass the root through the noose. Tighten the noose around the collar then twist the root around the string and wrap in parafilm. In a large beaker, immerse completely the rosettes first in distilled water for a few seconds in recovering solution. Put the beaker with the immersed rosettes in a dessicator connected to a vacuum pump (Fig. 2B). Vacuum-infiltrate the rosettes for 2 min after starting the pump. Reintroduce carefully air in the dessicator after vacuum breakage (Fig. 2C). Transfer the infiltrated plants to a centrifuge tube, with the collar at about 1 $\mathrm{cm}$ at the edge of the tube (Fig. 2D). Paste the lower part of the root outside of the tube with adhesive tape. Introduce at the bottom of the centrifuge tube $300 \mu \mathrm{L}$ of recovering solution. Centrifuge infiltrated plants in swinging buckets at $200 \times g$ for 17 $\mathrm{min}$ at $20^{\circ} \mathrm{C}$ (see Note 5). Collect the apoplastic washing fluids with a micropipette and estimate the volume. Vacuum-infiltration and centrifugation should be repeated twice.

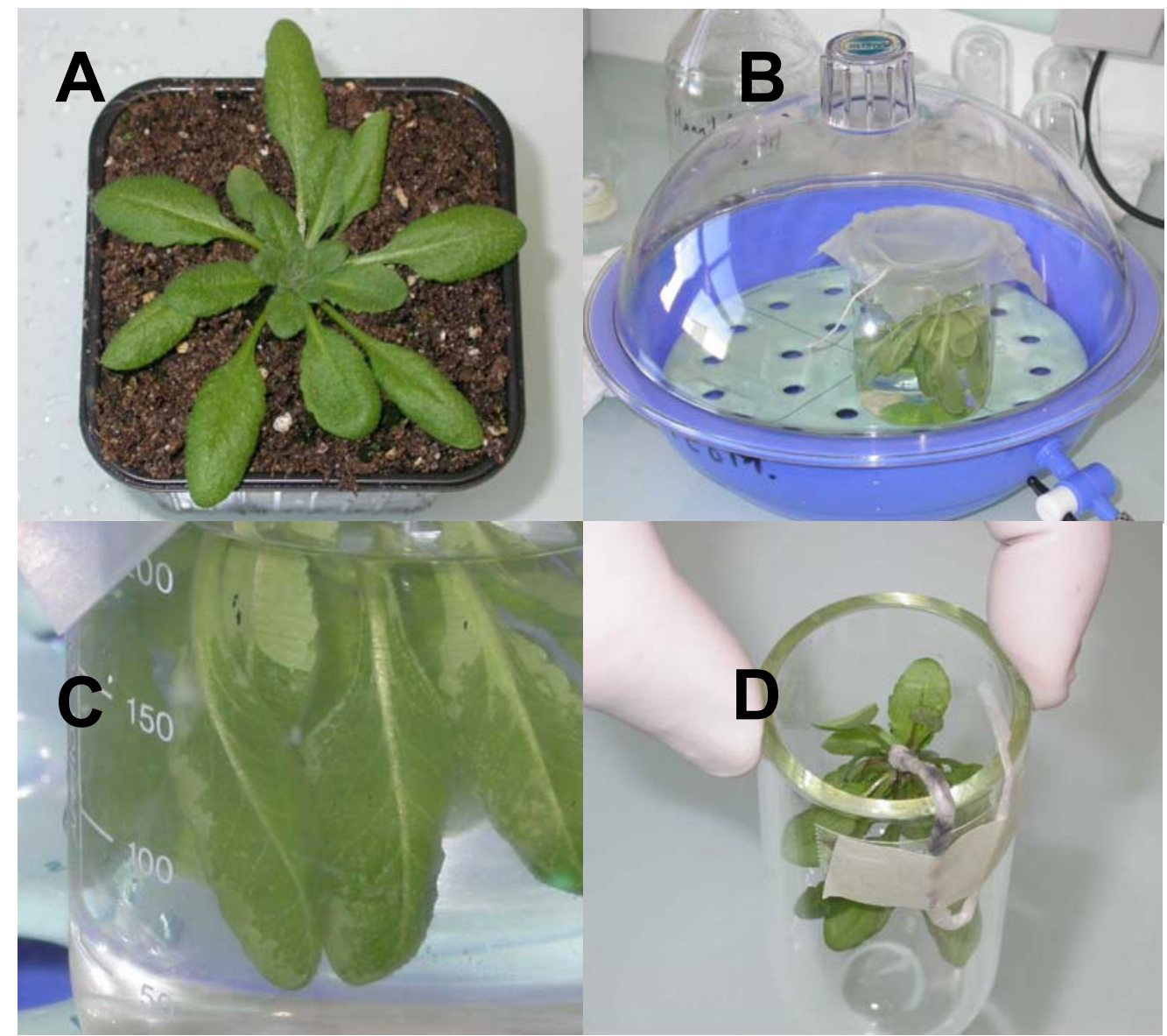

Fig. 2. Vacuum-infiltration of rosette leaves. Four steps of the procedure are illustrated: (A) 4-5 week-old plants; (B) vacuum-infiltration of immersed rosettes in a dessicator connected to a vacuum pump; (C) rosette leaves after vacuum-infiltration, note the darker part of a leaf after successful infiltration (black arrow); (D) infiltrated plant transferred to a centrifuge tube, note the drop of solution containing the protease inhibitor cocktail at the bottom of the tube (black arrow). 
3. Assay the apoplastic fluids for malate dehydrogenase (MDH) activity in order to detect cytoplasmic contaminations. Measure MDH activity at room temperature in 3 $\mathrm{mL} \mathrm{MDH}$ assay mixture and one-twentieth of the volume of the recovered apoplastic fluids. Reduction of NADP is followed at $\lambda=340 \mathrm{~nm}$. Pool only those apoplastic washing fluids with no detectable MDH activity.

4. Vacuum-infiltrate rosettes with R1, R2, R3 or R4 buffer. Check for MDH activity on the recovered apoplastic fluids as described above. Discard any apoplastic washing fluids with MDH activity. Pool the remaining apoplastic washing fluids free of MDH activity.

\subsubsection{Analysis of labile CWP by 2-DE}

1. Exhaustively dialyze the apoplastic washing fluids from rosettes infiltrated with the recovering solution at $4^{\circ} \mathrm{C}$ against deonized water in low binding $2 \mathrm{kDa}$ cutoff Spectra/Por ${ }^{\circledR}$ CE dialysis bags. Freeze-dry the dialysates. Resuspend the dry residues in $3 \mathrm{~mL}$ of resuspending solution and desalt on an Econo-Pac ${ }^{\circledR} 10 \mathrm{DG}$ desalting column equilibrated with desalting column equilibration buffer for the complete removal of mannitol. Freeze-dry the eluate.

2. Solubilize the dry residue in 2-DE sample buffer and separate proteins by 2-DE using a $7 \mathrm{~cm}-\mathrm{IPG}$ gel strip $\mathrm{pH}$ 4-7 for the first dimension.

\subsubsection{Analysis of weakly-bound CWP}

1. Exhaustively dialyze the apoplastic washing fluids from rosettes infiltrated with R1, R2, R3 or R4 buffer against Hi-Trap SP equilibration buffer as described above. Apply to a Hi-Trap SP Sepharose column equilibrated with Hi-Trap SP equilibration buffer at $1 \mathrm{~mL} \cdot \mathrm{min}^{-1}$. Elute the retained basic proteins with Hi-Trap SP elution buffer at 1 $\mathrm{mL} \cdot \mathrm{min}^{-1}$. Desalt the basic proteins on an Econo-Pac ${ }^{\circledR}$ 10DG desalting column equilibrated with desalting column equilibration buffer. Freeze-dry the eluate. Resuspend the dry residue in $40 \mu \mathrm{L}$ 1-DE sample buffer and separate proteins by 1-DE on a $10 \%-17 \%$ gradient SDS-polyacrylamide gel $(16.5 \times 13.5 \times 0.15 \mathrm{~cm})$.

2. Freeze-dry the acidic and neutral proteins in the Hi-Trap SP Sepharose column effluent. Solubilize the dry residue with a minimal volume of resuspending solution and desalt on an Econo-Pac ${ }^{\circledR}$ 10DG desalting column equilibrated with desalting column equilibration buffer. Freeze-dry the proteins and perform a 2-DE.

\subsection{Extraction of weakly bound CWP by destructive techniques}

\subsubsection{Cell wall preparation}

1. Soak A. thaliana ecotype Columbia seeds (see Note 2) in tap water for $2 \mathrm{~h}$, then sterilize in diluted bleach $(2.4 \%)$ for $45 \mathrm{~min}$, and rinse several times with deionized water. Sow the seeds $(150 \mathrm{mg})$ in a Magenta box $(6 \mathrm{~cm} \times 6 \mathrm{~cm})$ containing $50 \mathrm{~mL}$ of solid MS medium. Grow seedlings at $23^{\circ} \mathrm{C}$ in the dark for 11 days (see Note 6 ).

2. Harvest hypocotyls (around $2 \mathrm{~cm}$ high) of an average of 20 Magenta boxes as follows. First, remove carefully the solid MS medium carrying the seedlings from each box. Then, cut hypocotyls below cotyledons and above root with a pair of scissors. Wash the $1 \mathrm{~cm}$-long hypocotyls with distilled water onto a nylon net $(1.5 \mathrm{~mm}$ pore size $)$ to remove all the cut cotyledons and seed coats that stick to hypocotyls (see Note 7). Transfer the hypocotyls into $500 \mathrm{~mL}$ of grinding buffer and add PVPP $(1 \mathrm{~g} / 10 \mathrm{~g}$ fresh weight of hypocotyls) to complex phenolic compounds.

3. Grind the mixture in cold room using a Waring blender at full speed for $15 \mathrm{~min}$. 
4. Separate cell walls from soluble cytoplasmic fluid by centrifugation of the homogenate for $15 \mathrm{~min}$ at $1000 \times \mathrm{g}$ and $4^{\circ} \mathrm{C}$. Further purify the pellet by two successive centrifugations in $500 \mathrm{~mL}$ of cell wall purification buffers, $0.6 \mathrm{M}$ and $1 \mathrm{M}$ sucrose respectively.

5. Wash the residue with $3 \mathrm{~L}$ of cell wall washing buffer on a nylon net $(25 \mu \mathrm{m}$ pore size) in order to eliminate all soluble compounds. Grind the resulting cell wall fraction in liquid nitrogen in a mortar with a pestle prior to lyophilization. Starting with $16 \mathrm{~g}$ fresh weight of hypocotyls, this procedure usually results in $1.3 \mathrm{~g}$ dry powder.

\subsubsection{Extraction of proteins}

1. Typically, $0.65 \mathrm{~g}$ of lyophilized cell walls is used for one experiment. Extract proteins by successive salt solutions in this order: two extractions with $6 \mathrm{~mL} \mathrm{H1}$ buffer, followed by two extractions with $6 \mathrm{~mL} \mathrm{H} 2$ buffer. Resuspend cell walls by vortexing for 5-10 min at room temperature, and then centrifuge for $15 \mathrm{~min}$ at $4000 \times g$ and $4^{\circ} \mathrm{C}$. Supernatants from the same extracting buffer are pooled.

2. Desalt supernatants using Econo-Pac $\AA$ 10DG desalting columns equilibrated with desalting column equilibration buffer. Lyophilize the extracts and resuspend in $\mathrm{H}_{2} \mathrm{O}_{2}$.

3. Quantify proteins using the Bradford protein assay.

4. Add 1-DE sample buffer. Separate proteins by 1-DE on a $12.5 \%$ SDS-polyacrylamide gel.

\subsection{Analysis of CWP}

3.3.1. Specific constraints for separation by electrophoresis and protein identification by mass spectrometry

The separation of CWP by classical two-dimensional gel electrophoresis (2-DE) is difficult. Since most CWP are basic glycoproteins (Fig. 1C), they are poorly resolved by this technique (22). They are better separated by 1-DE. However, protocols including chromatographic steps to separate proteins prior to 1-DE are available $(\mathbf{2 4 , 2 5 )}$. In this chapter, a method able to separate acidic and basic CWP is proposed for a better resolution of these two types of CWP in 2-DE or 1-DE respectively.

Frequently, in 1-DE, proteins are not well separated from one another, and a protein sample can contain a mixture of proteins. However, the peptide mass mapping technology using high resolution $(<20 \mathrm{ppm})$ MALDI-TOF mass spectrometry (MS) permits the identification of several proteins from a mixture. Search engines such as MS-FIT from Protein Prospector (http://prospector.ucsf.edu/ucsfhtml4.0/msfit.htm) or MASCOT (http://www.matrixscience.com/search_form_select.html) allow multiple searches. In case of difficulties, proteins can also be identified by peptide sequencing using LC (liquid chromatography)-MS/MS systems (9).

\subsubsection{Use of bioinformatics for the evaluation of the efficiency of an extraction protocol}

The reliability of protein profiling for a compartment like the cell wall, strongly depends on the quality of the preparation. Unfortunately, the classical methods to check the purity of a particular fraction are not conclusive for proteomic studies, since the sensibility of the analysis by mass spectrometry is 10 to 1000 times more sensitive than enzymatic or immunological tests using specific markers. Our experience in the field has shown that the most efficient way to evaluate the quality of a cell wall preparation is (i) to identify all the proteins extracted from the cell wall by mass spectrometry, and (ii) to perform extensive bioinformatic analysis to determine if the identified proteins contain a signal peptide, and no 
retention signals for other cell compartments. Comparison of the results obtained with different programmes is necessary to ensure a reliable prediction: PSORT allows predicting any sub-cellular localization (http://psort.ims.u-tokyo.ac.jp/form.html); TargetP looks for the presence of signal peptides for protein secretion or of transit peptides for mitochondrion or chloroplast targeting (http://www.cbs.dtu.dk/services/TargetP/); Aramemnon compares the results of several programmes predicting the presence of signal peptides and trans-membrane domains (http://aramemnon.botanik.uni-koeln.de/). It is then possible to conclude about the quality of the cell wall preparation by calculating the ratio of predicted secreted proteins to intracellular ones.

\section{Notes}

1. Protease inhibitor cocktail for plant is required to prevent proteolysis during the extraction procedure. Proteolysis induces the production of smaller broken proteins that can be spread over 1-D or 2-D polyacrylamide gels. Thus, proteolysis can prevent the identification of both broken proteins and other proteins of interest by mass spectrometry. Moreover, the occurrence of these polypeptides is a great problem for quantitative and comparative proteomics.

2. Seeds germinate in culture media that are favourable to development of bacteria or fungi. Due to the high amount of seeds $(150 \mathrm{mg})$ introduced in a culture flask or in a Magenta box, the possible contamination events are multiplied. So, seeds should be carefully sterilized, and the healthy state of plants should be very good during their production in greenhouses.

3. Culture media should be processed immediately after recovery. Otherwise, proteolysis may occur even if they are stored frozen.

4. No more than two successive extractions with salt solutions should be performed. Otherwise, cells are damaged and intracellular contaminants are released in the culture medium and can stick non-specifically to cell walls (10).

5. Be careful setting minimal acceleration in order to avoid seriously damaging the vacuum-infiltrated plants during the centrifugation step. Imperatively centrifuge in swinging buckets to get undamaged plants during spinning.

6. All seedlings should grow at about the same rate to reach the same size after 11 days. If germination is not homogeneous, place the boxes at $6^{\circ} \mathrm{C}$ during 2 days to allow all seeds to start germination without growth. Then, all boxes can be put at $23^{\circ} \mathrm{C}$ for 11 days.

7. Cotyledons should be carefully removed. They contain few protein species but each of them in a huge amount. Due to their density, cotyledons co-sediment with cell walls. As a consequence, few cotyledons induce a significant contamination during extraction of cell wall proteins, especially by storage proteins. This contamination prevents the identification of proteins of interest by mass spectrometry.

\section{Ackowledgments}

The authors are grateful to the Université Paul Sabatier (Toulouse III, France) and the CNRS for support. 


\section{References}

1. Hunter, T.C., Andon, N.L., Koller, A., Yates, J.R. and Haynes, P.A. (2002) The functional proteomics toolbox: methods and applications. J. Chromatogr. B 782, 161181.

2. Carpita, N. and Gibeaut, D. (1993) Structural models of primary cell walls in flowering plants: consistency of molecular structure with the physical properties of the walls during growth. Plant J. 3, 1-30.

3. Cosgrove, D.J. (2005) Growth of the plant cell wall. Nat. Rev. Mol. Cell. Biol. 6, 850861.

4. Jamet, E., Canut, H., Boudart, G. and Pont-Lezica, R.F. (2006) Cell wall proteins: a new insight through proteomics. Trends Plant Sci. 11, 33-39.

5. Varner, J.E. and Lin, L.-S. (1989) Plant cell wall architecture. Cell 56, 231-239.

6. Brady, J.D., Sadler, I.H. and Fry, S.C. (1996) Di-isodityrosine, a novel tetrameric derivative of tyrosine in plant cell wall proteins: a new potential cross-link. J. Biochem. 315, 323-327.

7. Schnabelrauch, L.S., Kieliszewski, M.J., Upham, B.L., Alizedeh, H. and Lamport, D.T.A. (1996) Isolation of pI 4.6 extensin peroxidase from tomato cell suspension cultures and identification of Val-Tyr-Lys as putative intermolecular cross-link site. Plant J. 9, 477489.

8. Shah, K., Penel, C., Gagnon, J. and Dunand, C. (2004) Purification and identification of a $\mathrm{Ca}^{+2}$-pectate binding peroxidase from Arabidopsis leaves. Phytochem. 65, 307-312.

9. Boudart, G., Jamet, E., Rossignol, M., Lafitte, C., Borderies, G., Jauneau, A., EsquerréTugayé, M.-T. and Pont-Lezica, R. (2005) Cell wall proteins in apoplastic fluids of Arabidopsis thaliana rosettes: Identification by mass spectrometry and bioinformatics. Proteomics 5, 212-221.

10. Borderies, G., Jamet, E., Lafitte, C., Rossignol, M., Jauneau, A., Boudart, G., Monsarrat, B., Esquerre-Tugaye, M.-T., Boudet, A. and Pont-Lezica, R. (2003) Proteomics of loosely bound cell wall proteins of Arabidopsis thaliana cell suspension cultures: a critical analysis. Electrophoresis 24, 3421-3432.

11. Charmont, S., Jamet, E., Pont-Lezica, R. and Canut, H. (2005) Proteomic analysis of secreted proteins from Arabidopsis thaliana seedlings: improved recovery following removal of phenolic compounds. Phytochem. 66, 453-461.

12. Held, M.A., Tan, L., Kamyab, A., Hare, M., Shpak, E. and Kieliszewski, M.J. (2004) Diisodityrosine is the intermolecular cross-link of isodityrosine-rich extensin analogs crosslinked in vitro. J. Biol. Chem. 279, 55474-55482.

13. Miller, J.G. and Fry, S.C. (1992) Production and harvesting of ionically wall-bound extensin from living cell suspension cultures. Plant Cell Tissue Organ Cult. 31, 61-66.

14. Murashige, T. and Skoog, F. (1962) A revised medium for rapid growth and bioassays with tobacco tissue culture. Physiol. Plant. 15, 473-497.

15. Loomis, W.D. (1974) Overcoming problems of phenolics and quinones in the isolation of plant enzymes and organelles. Meth. Enzymol. 31, 528-545.

16. Ramagli, L.S. and Rodriguez, L.V. (1985) Quantitation of microgram amounts of protein in two-dimensional polyacrylamide electrophoresis sample buffer. Electrophoresis 6, 559-563.

17. Axelos, M., Curie, C., Mazzolini, L., Bardet, C. and Lescure, B. (1992) A protocol for transient gene expression in Arabidopsis thaliana protoplasts isolated from cell suspension cultures. Plant Physiol. Biochem. 30, 123-128.

18. Voigt, J. (1985) Extraction by lithium chloride of hydroxyproline-rich glycoproteins from intact cells of Chlamydomonas reinhardii. Planta 164, 379-389. 
19. Smith, J., Muldoon, E. and Lamport, D. (1984) Isolation of extensin precursors by direct elution of intact tomato cell suspension cultures. Phytochem. 23, 1233-1239.

20. Angyal, S. (1989) Complexes of metal cations with carbohydrates in solution. $A d v$. Carbohydr. Chem. Biochem. 47, 1-44.

21. van Buren, J. (1991) Function of pectin in plant tissue structure and firmness in, The Chemistry and Technology of Pectin (Walter, R. H. ed.), Academic Press, New York, pp. $1-22$.

22. Bardy, N., Carrasco, A., Galaud, J.P., Pont-Lezica, R. and Canut, H. (1998) Free-flow electrophoresis for fractionation of Arabidopsis thaliana membranes. Electrophoresis 19, 1145-1153.

23. Rabilloud, T. (2002) Two-dimensional gel electrophoresis in proteomics: old, old fashioned, but still climbs up the mountains. Proteomics 2, 3-10.

24. Stasyk, T. and Huber, L.A. (2004) Zooming in fractionation strategies in proteomics. Proteomics 4, 3704-3716.

25. Lescuyer, P., Hochstrasser, D.F., Sanchez, J.C. (2004) Comprehensive proteome analysis by chromatographic protein prefractionation. Electrophoresis 25, 1125-1135. 